\title{
전통춤 디지털 콘텐츠에 관한 문화예술정책 연구 Culture and Art Policies of Korean government for Traditional Dancing Digital Contents
}

\author{
김지원, 류지성 \\ 단국대학교 행정학과
}

\author{
Ji-Won Kim(hyunjudance@hanmail.net),Ji-Sung Rhyu(sundevil@dankook.ac.kr)
}

\section{요약}

세계적으로 한류 붐이 일면서 한국문화가 세계의 중심에 자리잡고 있는데 이로 인해 생겨난 부가가치는 측정하기 어려울 정도로 크다. 이에 따라 한국 전통춤의 원형을 보존하는 일과 디지털 콘텐츠화 작업은 정 부만의 일에 그치지 않고 막대한 부가가치 가능성 때문에 문화산업측면에서 민간 부문이 관심을 크게 기울 이고 있다. 그 목적을 달성하기 위해서는 콘텐츠 개발이 시급하기는 하나 한국 전통 춤의 원형의 가치를 확립하는 일이 선행되어야 한다. 대중은 문화적 가치를 재발견하는데 있어서 적극적 역할을 해야 하며 한국 인의 정체성을 대표하는 전통 춤은 체계적인 예술정책의 대상이 되어야 한다.

이 논문은 전통춤 디지털 콘텐츠 개발의 실태를 점검해보고자 한다. 또한 문화원형을 보존하는 것이 지닌 현대적 가치를 재조명해봄으로써 가까운 미래의 문화예술정책의 방향에 관해 제언하고자 한다.

연구를 통해 전통춤의 원형에 관한 전문 인력이 부족한 점과, 역사적 고증 절차의 신뢰성을 점검해야할 필요가 있음을 확인했다. 산학협력단의 협동과제와 전문 인력 배치에도 불구하고 민간 기업이 인력을 양성 할 수 있는 정책적 지원은 여전히 미흡한 실정이다. 즉 인력 양성과 자원 배분, 예산 확보, 민간 분야와 개인 의 협력 증진, 민간 기업의 산업적 차원에서의 관심은 부족하다. 이는 문화 원형이 즉각 수입을 창출해주는 비즈니스가 아니기 때문이다. 따라서 비즈니스 지향적인 회사가 전통춤을 불가피한 요소로 인식하는 경우 도 없으며 그러한 시도도 아직 없다. 이를 위해서는 콘텐츠 개발이라는 하드웨어적인 정량적 정책보다 대중 의 소통과 참여와 나눔을 통해 문화수요를 촉진하는 소프트웨어적 정책이 우선 추진되어야 한다. 이를 통해 전통춤의 가치에 대한 자연스런 인식 변화를 유발할 수 있다. 이러한 정책을 통해 전통춤은 문화의 창조적 보고로서, 또한 경제적 가치를 만들어내는 공공산업으로 새롭게 인식될 것이다.

- 중심어 : | 문화예술정책 | 전통춤 디지털 콘텐츠 | 전통춤 문화원형 |

\section{Abstract}

It is the time of the Korean Wave booming throughout the world, placing Korean culture in the center of the world and its added value is unaccountable. At this prosperity, the preserving of the archetype of Korean dancing and digital contents making is becoming a task not only for the government but also for the private sector because culture industry has enormous added values. To achieve such goals, contents development is an urgent matter but establishing the value of the archetype of Korean traditional dancing must have priority. The public has to take an active role in rediscovering the values of traditional culture, and as the representative of Korean identity traditional dancing must be the object of a systematic art policy.

This study will review the current status of 'digital contents program of the archetype of culture' for traditional dancing and will reconsider the modern value of preserving the archetype of culture to make a suggestion to the direction of culture art policies in the near future.

The study acknowledged the lack of technical personnel majoring in the archetype of traditional dancing and the need of reviewing the credibility of historical research procedures. Even with the studies by industry-university collaboration and positioning of specialists, effective policies that will form the foundation for private firms to train personnels is in urgent need. In other words, training personnels, allocation of resource, securing funds, policies promoting collaboration between private and individual businesses, and the commercial recognition at private firms are still far from establishing.

This is due to the fact that archetype of culture is not a business that creates revenue immediately, therefore the recognition of traditional dancing as an investable item by business-oriented firms or movements are difficult to find. To overcome such situation, software oriented policies that establish open communication and sharing with the public should be done at first rather than the quantity oriented hardware policies of contents development. Through this process the public can change the attitude on traditional dancing and traditional dancing could be newly recognized as a creative repository of culture and as public businesses giving birth to economic value.

- keyword : | Culture and Art Policies | Traditional Dancing Digital Contents | Archetype of Korean Dancing |

접수번호 : \#120730-003

접수일자 : 2012년 07월 30일
심사완료일 : 2012년 09월 10일

교신저자 : 류지성, e-mail : sundevil@dankook.ac.kr 


\section{I. 머리말}

\section{1. 연구목적}

문화는 동시대에 동일한 공간에서 집단 구성원이 공 동생활을 영위하며 일정한 목적이나 생활의 이상을 구 현하려는 활동과 그에 따른 결과물을 뜻한다.

문화는 국가와 민족에 따라 다른 모습을 보이며, 같은 나라에서도 지역에 따라 다른 양상을 띠게 된다. 한국의 전통춤도 마찬가지이다. 전통춤과 같은 문화원형은 민 족의 정서를 대변하는 공감대를 형성하고 그 문화의 정 체성을 상징한다. 바꿔 말해 전통춤은 한국예술을 대표 하는 보편 틀로서, 문화 원형의 한 가지라고 할 수 있다. 이러한 역사적·전통적 문화예술이 국문학·민속학·철학. 문화인류학 등과 한데 어우러져 협동 체제를 구축하면 서 원천소스로 활용될 수 있도록 하는 작업이 문화원형 디지털콘텐츠 사업이다. 문화원형 디지털 콘텐츠 사업 에서 가장 핵심이 되는 요소는 '디지털화'이다.

지금까지 전통놀이와 춤을 포함한 전통문화유산을 디지털화하는 작업은 주로 복원 차원에서 다루었으며, 디지털화와 맞물려 다양한 형태의 디지털 결과물을 생 성해왔다. 문화유산의 복원만으로도 한국의 전통문화 는 부활해 발전해 갈 가능성을 제시해 주었다. 콘텐츠 로서 상품 가치만 보아도 인문학적 지식과 디지털 기술 이 접목되면 경쟁력 있는, 다시 말해 고부가가치를 실 현할 수 있는 가능성이 커진다.

문화와 기술의 결합체인 문화기술(Culture Techno$\operatorname{logy})$ 은 콘텐츠의 기획과 제작, 유통에 이르기 까지 콘 텐츠 전반에 걸친 기술이다. 2008년 수립된 '문화기술 $\mathrm{R} \& \mathrm{D}$ 기본계획'에는 문화원형 콘텐츠를 위한 중점과제 로 ‘지능형 디지털 문화 체험'을 위한 문화유산상태/영 상구조화, 문화원형 추정 자동화, 실감 체험형 가상관광 시스템 등을 개발하기 위한 핵심 기술이 포함되어 있다.

하지만 전통춤 문화원형의 관점에서 바라보면 이 시 기 이후 전통춤 복원에 대한 관심은 핵심에서 빗겨난 것으로 보인다. 춤이 가장 원초적인 감성예술로서 많은 학문적 연구가 이뤄져왔음에도 불구하고, 현재 '콘텐츠 개발'이라는 고부가가치의 당위적인 명제에 대해 대중 의 관심이 이에 부응하지 못한 관계로 정책적 기반이
소홀한 상태라고 할 수 있다.

전통춤 원형의 디지털화는 무궁무진한 소재를 제공 해 줄 수 있는 한국의 대표 예술장르임에 틀림없다. 그 런데 한국의 전통춤은 근대화 단계에서의 문화예술 변 천과정에서 대중의 급격한 태도 변화에 제대로 적응하 지 못했다. 춤 원형을 위한 좀 더 세분화 된 전문 인력의 양성이나, 대중화를 위한 마케팅 또는 참여예술에 관한 한국문화예술의 정책 마련에서도, 해방과 전쟁 이후 급 변하는 경제상황에 맞물려 전통문화유산 가운데 춤만을 위한 정책을 세우고 집행하기 힘들었기 때문이다.

그러나 바야흐로 때는 한류 열풍으로, 지금 한국의 문화는 세계의 중심에 서있으며 그 부가가치는 어마어 마하다. 이러한 시점에서 한국 춤의 문화원형과 디지털 콘텐츠화는 정부 뿐 아니라 민간 부문에서도 고부가가 치 가능성 때문에 관심을 크게 기울이고 있다. 콘텐츠 개발도 중요하지만 이보다 더 시급한 과제는 한국 전통 춤 원형의 가치를 재조명해보는 것이라고 생각한다. 이 는 대중이 문화적 가치관의 변화를 주도해야 한다는 것 을 의미한다. 또 한국의 보편적 정체성을 대표하는 예 술로서 전통춤이 자리매김할 수 있도록 예술정책이 체 계화되어야 함을 뜻한다.

따라서 본 연구는 전통춤 디지털 콘텐츠화의 '문화원 형 디지털 사업'에 대해 현황을 살피고, 원형복원의 현 대적 가치를 새롭게 재조명하면서 문화예술정책이 나 아가야 할 방향성에 대해 살펴본다.

\section{2. 연구의 절차 및 제한점}

본 연구는 한국의 문화예술정책 개념과 시대적 변천 에 관해 문헌을 중심으로 살펴본 다음 전통춤을 중심으 로 현재까지 이뤄진 문화원형 디지털콘텐츠화의 현황 및 현대적 가치를 재조명해 본다. 이어서 정책이나 문 화산업현장에서 어떻게 활용되고 있으며 향후 개선점 은 무엇인지 알아본다.

본 연구는 디지털콘텐츠 정책 방안을 살펴보는 데 있 어서 문화정책의 거시적인 측면에서 몇 가지 제한을 두 기로 한다.

첫째, 콘텐츠의 현황 분석은 '전통놀이와 춤에서 가장 하여 등장하는 인물의 디지털콘텐츠 개발' 과제와 같이, 
여러 전통놀이 가운데 비교적 춤을 중심 소재로 한 원 형개발로 연구 대상을 국한하기로 한다. 예를 들어 탈 놀이를 소재로 한 문화원형과제에는 탈춤도 포함되어 있으나, 탈과 민속학적 관점에서 집중적인 디지털 자료 를 토대로 하고 있다는 점에서 춤 원형과제에서는 제외 하기로 한다.

둘째, 본 연구는 춤의 디지털 콘텐츠의 현황에 대해 일반적인 재조명이기 때문에 춤 명칭에 관한 역사적 유 래나 춤사위, 복식에 관한 무용학적 논의는 모두 생략 한다. 한편 춤 문화정책에 관한 문예진흥정책의 모든 총괄과 업무현황, 정부 관련 기관의 관련 콘텐츠 개발 사업 현황에 관해서는 논문 작성시 참고자료로 활용했 으며 수록하지 않는다. 또한 디지털콘텐츠 방안을 논할 때 전통춤 인식변화와 콘텐츠가 나아가야 할 방향에 관 한 일반적 문화정책에 기반을 두고 논의를 진행했음을 밝힌다. 정부 차원의 한국 춤 원형 디지털 콘텐츠화 개 발은 2008년 이후 사실상 중단되고 있어 최근 자료가 없음에 주목할 필요가 있다.

\section{II. 문화예술정책과 디지털콘텐츠}

\section{1. 문화예술정책의 개념과 시대적 변천}

'정책'의 개념에 대해 이스턴[1]은 "정책이란 최소한 사회적 가치의 권위적인 배분"이라고 하였다. 노시평 [2]은 샤르칸스키(Sharkansky)[3]의 개념 정의를 빌어 정책을 정부의 중요 활동으로 규정하면서 정부의 중요 활동은 (1) 사회적 가치배분을 위한 권위 있는 의사결정 을 하는 활동, (2) 사회가 직면한 공공문제의 해결을 위 한 활동 (3) 어떤 사회를 어떻게 만들 것인가 하는 데 대 한 설계와 관련된 활동이라 하겠다[4]. 즉 정책은 권위 있는 기관으로서의 정부가 공공의 목적을 달성하기 위 해 반드시 필요하다고 판단해서 만들어 놓은 행동 지침 을 뜻한다.

한국의 전통문화 예술의 기반은 개화기 이후 신문물 이 범람하면서 흔들리게 되었고 한국의 문화 정체성 역 시 위기에 놓였다. 이에 따라 전통문화예술을 보호할 필요성이 강력히 제기되기 시작했다. 서구문화와 대비
되는 뜻에서의 전통문화가 본격적으로 국가적 관심 대 상이 된 시기는 1948년 대한민국 건국 이후다. 물론 국 가의 전통공연예술정책 수행 기관으로서 국립국악원의 경우 7세기 신라시대 이래 1,400 여 년간 왕립 예술기관 으로 존속해온 제도를 이어 받은 것으로 20세기 이전에 공연 예술정책이 전무했다고 할 수는 없다[5]. 그러나 당시는 국가의 연희나 의전 행사 때 고유 예술을 관장 하고 연희를 주관하는 기관이 존재했을 뿐, 전통예술에 관한 조직적인 제도 개편이나 확장, 가치실현을 위한 정책적 체계로 보기는 어렵다.

그 후 문화예술과 관련된 논의는 정부 주도 하에 진 행되어 왔다. 일제 강점기에 상실한 전통 문화의 가치 를 새로이 인식하는데 혼란이 있었을 뿐만 아니라 서구 적 문물의 영향을 넘어서 사회에 재정착하게 하려는 정 책이 효과를 거두기란 결코 쉬운 일이 아니었다. 어려 운 환경 속에서도 1950 년 민족예술 진흥과 무대예술 발 전을 위한 국립극장의 발족, 1951 년 전통 악가무의 보 존과 계승을 위한 국립국악원 발족 등이 이뤄졌다.

이러한 상황에서 해방과 곧이은 한국전쟁의 영향으 로 미국 문화가 대대적으로 유입되면서 한국의 전통문 화는 단절의 위기를 다시 맞이한다. 미국 사회의 상류 라고는 볼 수 없는 미군병사 문화, 미국의 대중문화를 모방해 급조된 일본의 대중문화가 밀려 들어오면서 한 국의 전통적인 문화요소를 무조건 열등하게 취급하는 오류를 범하게 되는 것이다[6]. 문화의 자생력을 키워야 하는 단계에서 전통에 대한 가치 인식이 형편없이 낮은 바람에 위기 국면을 맞게 되면서 국가적인 차원에서 전 통 생활문화나 풍습, 민속놀이, 전통춤과 악기 등을 정 책적으로 뒷받침할 필요성이 더욱 커졌다. 1962년 문화 재보호법이 문화예술정책을 총괄하는 제도로 등장했다. 이후 한국 문화예술정책은 크게 다음과 같은 변화를 거친다.

\section{표 1. 한국 문화예술정책의 변천[7]}

\begin{tabular}{|c|c|c|}
\hline $\begin{array}{c}\text { 정책 } \\
\text { 형성기 } \\
\text { (1961- } \\
1973)\end{array}$ & $\begin{array}{c}\text { 문화재 } \\
\text { 보호법 } \\
\text { 제정 } \\
\text { (1962) }\end{array}$ & $\begin{array}{l}\text { 일본의 문화재보호법을 토대로 한국에 '문화재 } \\
\text { '란 용어가 첫 등장. } \\
1961 \text { 년 '공연법'을 제정해 연극, 무용, 음악 등 } \\
10 \text { 개 문화예술단체를 회원으로 한 사단법힌 한 } \\
\text { 국예술문화단체총연합회 설립. } \\
1972 \text { 년 '문화예술진흥법' 제정, } \\
1973 \text { 년 문예진흥원 설립. 문화예술진흥기금 } \\
\text { 부과, 국립극장 건립. }\end{array}$ \\
\hline
\end{tabular}




\begin{tabular}{|c|c|c|}
\hline $\begin{array}{l}\text { 전통문화 } \\
\text { 확산기 }\end{array}$ & $\begin{array}{l}\text { 문예중흥 } \\
\text { 5개년 } \\
\text { 계획 } \\
\text { 및 } \\
\text { 신군 } \\
\text { 부정권기 } \\
\text { (1974- } \\
1989)\end{array}$ & $\begin{array}{l}\text { 문예중흥 } 5 \text { 개년 계획 집행. } 70 \% \text { 이상이 문화 } \\
\text { 재, 국학개발, 전통예술개발 등 전통문화부문 } \\
\text { 에 집중 투자됨. } \\
\text { 국악고등학교 설립, 국학교육이나 국악대연주 } \\
\text { 단의 운영 대폭 지원. } \\
\text { 새마을 운동으로 농촌문화파괴가 조직적으로 } \\
\text { 전개되면서 전통적인 유. 무형문화재가 미신이 } \\
\text { 라는 비판 속에 일거에 해체됨. } \\
1981 \text { 년 전두환 정부는 개헌시 민족문화창달 } \\
\text { 을 목표로 한 문화발전을 명시, 문화투자의 대 } \\
\text { 폭적 확대와 문화시설을 전국적으로 조성. }\end{array}$ \\
\hline 전환기 & $\begin{array}{c}\text { 문화부 } \\
\text { 신설 } \\
\text { 및 } \\
\text { 문민정부 } \\
\text { (1981- } \\
1998)\end{array}$ & $\begin{array}{l}\text { 노태우 정부는 문화부 신설과 함께 '문화발전 } \\
10 \text { 개년 계획( } 1990-1999) \text { '를 수립하여 "모 } \\
\text { 든 국민에게 문화를"이라는 정책목표를 설정하 } \\
\text { 고 새로운 문화전략으로 "문화주의"를 표방. } \\
\text { 문화를 관리하고 통제하고 규제하는 기관에서 } \\
\text { 지역문예활동 지원을 강화하거나 예술창작 지 } \\
\text { 원사업의 확대 등 참여하는 예술 활동에 초점. } \\
\text { 예술인을 위한 창작공간의 확대, 한국예술종합 } \\
\text { 학교의 신설(1992). }\end{array}$ \\
\hline 성숙기 & $\begin{array}{l}\text { 문화재청 } \\
\text { 발족이후 } \\
\text { (1999-) }\end{array}$ & $\begin{array}{l}\text { 국민의 정부, } 2000 \text { 년 정부예산의 } 1 \% \text { 이상으로 } \\
\text { 문화예산 늘림. 문화재보호법 개정. } \\
\text { 기,예능보유자 명예보유자 제도를 도입. 문화 } \\
\text { 재청 기관장은 } 2 \text { 급에서 } 1 \text { 급으로 상향 조절, } \\
\text { 직제 확대개편은 불발. } \\
\text { 참여정부, } 2003 \text { 년 건조물국 신설.문화재정보 } \\
\text { 과, 동산문화재과, 근대문화재과 신설, 문화재 } \\
\text { 기술과 폐지, 문화재정책과 신설. }\end{array}$ \\
\hline
\end{tabular}

문화예술정책은, 국가가 행정적 업무의 일환으로 공 권력을 사용하여 제반 업무를 추진해가는 과정[8]에서 다양한 사회적 현상에서 비롯된 공공문제를 해결 한다 는 차원에서 새로이 인식되어야 한다. 한국의 문화예술 정책은 문화를 통해 한국에 대한 인식을 새롭게 하고 문화 마케팅 등을 통해 공공 부가가치를 높이는 한편 문화의 정체성을 확립해야 하는 과제를 안고 있다. 이 를 위해서는 공권력을 가진 정부가 문화를 통해 사회적 자원을 배분하고 예술 정책을 통해 국민의 정서적 욕구 를 충족시키는 정책을 펼쳐 나아가야 한다.

문화예술정책의 기본 요소는 문화 인프라 구축, 예술 인 육성, 문화소비자 지원 등이다. 이들 요소는 상호 우 열을 가릴 수 없을 만큼 문화예술진흥 단계에서 모두 중요하다. 문화예술정책은 단지 문화예술을 관리하는 차원에서 문화재 지정의 원형보존이나 시설기관의 확 충이나 자료수집의 수급 또는 $\mathrm{DB}$ 구축을 하는데 그쳐서 는 안된다. 즉 인적 - 물적 자원의 효율적 관리 또는 참 여 활동, 혹은 국제화를 위한 체계적 문화홍보 등이 아 울러 전개되어야 한다. 전통문화예술의 가치를 확산하 고 문화예술정책의 대중화를 통해 한류라는 국가브랜
드의 정체성을 확고히 하기 위해서는 보다 면밀하고 구 체적인 문화예술정책 방안이 갖춰지지 않으면 안된다 는 것을 의미한다.

\section{2. 전통춤 문화원형 디지털콘텐츠}

1996년 유네스코는 한국의 무형문화재 제도가 무형 문화재 보호를 위하여 본받을만한 가장 모범적인 제도 임을 확인하고 전 세계가 사라져 가는 무형 문화유산을 보호할 것을 촉구하는 결의문을 채택한다. 이 때 한국 의 무형문화재제도를 세계에 보급하는 성과를 거두며 공예사기장 등 10 개 공예종목을 새로 발굴지정하여 침 체되어 있던 공예의 전승에 활력을 불어 넣었다[9].

정부는 1997년을 '문화유산의 해’로 지정하여 전통문 화에 대한 다양한 시책을 추진하였으며 이에 따라 사회 일반의 문화활동에 대한 참여의 폭이 커졌으며 일반인 사이에 전통문화에 대한 관심이 확대되는 계기가 되었 다. 문화유산의 이념인 '문화유산헌장'이 제정되었으며 중요무형문화재 전승자들의 숙원이었던 무형문화재 종 합전수회관이 서울 강남구에 건립되면서 전승 활동에 활력소가 되었다.

이처럼 유형 뿐 아니라 무형의 문화재에 관심을 둔 정책의 연장선에서 전통춤에 대한 양성책도 중요한 전 기를 맞는다. 문화재 전수회관에서는 전통춤의 홍보 및 전수조교와 문화재의 선발 등 많은 활동이 개시됐다. 또한 이에 그치지 않고 한국 전통춤의 대중화를 위해 다양한 기관과 협력 체제를 구축하게 된다. 한국 전통 춤의 대중화와 문화적 부가가치를 창출하기 위한 정책 가운데 디지털 콘텐츠화가 매우 중요한 핵심과제로 부 상하게 되었다.

\section{1 문화원형과 디지털콘텐츠}

문화원형은 전통문화 가운데 그 민족 또는 그 지역의 특징을 잘 담고 있어서 다른 지역, 다른 민족과 구별되 며, 아울러 여러 가지로 갈라진 현재형의 본디모습에 해당되는 문화를 말한다[10]. 문화콘텐츠산업에서 문화 원형이라는 용어가 본격적으로 등장한 계기는 2002년 시작된 한국콘텐츠진흥원의 문화원형 관련 사업이다. 문화관광부는 1999년 '문화산업발전 5개년 계획'과 
2001년 '콘텐츠코리아 비전 21'을 수립해 발표하였다. 같은 해 한국문화콘텐츠진흥원이 설립되면서 한국 문 화콘텐츠에 대한 개발은 출판, 엔터테인먼트, 캐릭터, 애니메이션, 방송, 광고, 영화, 음악, 게임, 미술, 공연, 디지털 교육 및 정보 등 21세기 신지식사업으로 무한한 시장의 가능성을 열고 있다.

‘콘텐츠’란 ‘부호, 문자, 음성, 음향 및 영상 등의 자료 또는 정보'(문화산업진흥기본법 제 2조)를 칭하며, 디지 털 콘텐츠란 '이러한 정보에 대해 보존 및 이용에 효용 성을 높일 수 있도록 디지털 형태로 제작 또는 처리한 것'(문화산업진흥기본법 제 2조)을 의미한다[11].

문화콘텐츠는 단순한 지식이나 정보가 아닌 예술의 확장개념이자 상품으로까지 연결되는 고부가가치의 산 물을 통칭한다. 문화산업을 향한 다양한 모색과 고부가 가치를 위한 도전은 전통문화를 보존하고 가꾸기 위한 소극적 방어전략에서 벗어나 상업적 이윤뿐 아니라 자 국민에게 문화적 긍지를 심어주는 대상으로까지 확장 되고 있다. 문화콘텐츠가 고부가가치의 고도 성장산업 으로 떠오른 것은 창의적 아이디어가 경쟁력의 원천이 되는 시대의 등장과 무관하지 않다.

인간의 창의력과 지식이 집약된 디지털 기술과 미디 어의 융합은 민족문화를 재해석해 새 문화를 창출하는 또 하나의 예술영역으로 자리한다. 따라서 콘텐츠 기획 과 제작, 유통, 소비에 관한 전 과정에 대한 산업적 마인 드뿐 아니라, 창의력 있는 원천 개발과 새로운 응용에 이르는 아이디어 등이 경쟁력을 갖게 되었다. 최근에는 문화콘텐츠간의 융합으로 장르 구분이 모호해질 만큼 새로운 응용과 시도가 이루어지고 있으며 참신한 창작 소재들이 주목받고 있다.

문화콘텐츠의 발전을 도모하는 계기는 중요한 요소 들의 융합과 상호교류와 지식정보의 나눔이다. 그 중 가장 대표적인 것이 바로 $\mathrm{CT}($ Culture \& Contents Technology)기술의 발달이다. CT기술은 단순한 이공 학적 기술을 의미하는 것이 아니다. 위에서 언급한 다 각적인 학문적 시스템의 구축으로 이·공학 뿐 아니라 인문사회, 디자인학, 예술학 등의 복합적 기술을 아우르 는 개념이다[12].

현재 여러 나라에서는 문화콘텐츠산업을 국가미래 전략사업으로 선정하고 정책적 지원을 강화하고 있다.
한국 또한 한국전산원 중심의 국가지식콘텐츠디지털 화, 정부통신부 중심의 온라인 디지털콘텐츠 산업 발전 법, 문화관광부중심의 문화콘텐츠진흥사업 등 여러 분 야로 확대되고 있다.

특히 문화관광부의 한국문화콘텐츠진흥원의 설립은 문화콘텐츠의 다양성을 토대로 국가적 인프라를 구축 하여 대중과의 융합과 소통을 이끌어 낼 수 있는 중요 한 시발점이 되었다. 그 중 가장 활발하게 추진되는 '문 화원형 디지털콘텐츠화 사업’은 문화원형을 문화콘텐 츠 창작의 보고(寶庫)로 여기고, 지식문화산업을 기획 하고 제작자에게 창작소재를 제공하는 것을 목적으로 한다.

문화원형 디지털콘텐츠화 사업은 크게 상상(신화, 전 설, 민담, 역사, 문학 등 이야기형 소재), 감동(회화, 서 예, 복식, 문양, 음악, 춤 등 예술형 소재), 역동(전투, 놀 이, 외교, 교역 등 경영 및 전략형 소재), 지혜(건축, 지 도, 농사, 어로, 음식, 의학 등 기술형 소재)를 주요개발 분야로 나누고 있다.

2007-2011년의 문화원형 디지털콘텐츠화 제 2차 기 본계획에는 창작인프라를 지속강화하는 한편 한국형스 토리텔링의 발굴과 문화상품 기획 및 창작의 연계지원 등 다양한 창작 소재의 활용마케팅에도 주력하고 있다. 문화원형 디지털 콘텐츠화사업 176 개 과제는 문화콘텐 츠 닷컴을 통해 공개되어 있다. 이 중 전통춤은 다른 분 야에 비해 적은 사업만 추진하고 있으나 장기적이고 체 계적인 비전과 로드맵의 출발을 뜻하는 점에서 의미 깊 다. 향후 추가적인 발전이 기대된다.

문화원형 디지털콘텐츠화는 산업화에 무감각했던 예 술분야에 고부가가치를 창출하는 상생적 협력모델이 등장하는 계기가 되었고, 다양한 문화콘텐츠의 활용도 를 높이기 위한 원천의 중요성을 각인시켰다. 또한 한 국의 역사, 전통, 생활, 예술, 지리 등 다양한 분야에서 상상력의 원천인 창작의 소재를 개발해 예술가들에게 도 창작의 지평을 넓혀주는 계기가 되고 있다.

나아가 전통문화예술의 원형 개발과 발전은 문화적 특수성을 넘어서 세계화를 향한 보편적 글로벌 가치를 재발견한다는데 더 큰 의의가 있다. 


\section{2 전통춤 문화원형 디지털콘텐츠화 현황 및 가치 재}

\section{조명}

문화원형의 디지털콘텐츠 가운데 전통춤 콘텐츠는 시대의 변화에 발맞추어 춤이 가진 다양한 가치와 상품 화, 한류의 문화적 고유성을 부각할 수 있는 기획적 전 략이라 할 수 있다. 즉 지난날 전통문화예술은 정부의 노력에도 불구하고 단절되고 소멸되어, 어느 한 부분만 이 강조되거나 지나치게 저급화되어 대중의 관심에서 소외되어 있었다. 이러한 점에서 전통춤의 디지털화는 상품가치를 잃어버렸던 전통춤의 인식적 측면에서 어 느 정도 효과적인 기획의 한 부분이라 할 수 있다.

다시 말해 전통춤 디지털콘텐츠는 우리문화의 원형 을 찾아 춤의 가치를 인식하고 오랜 역사와 전통을 지 닌 예술로서 문화의 정체성을 회복할 수 있다. 또한 공 연위주의 관람형 춤 예술의 성향을 탈피하고 춤 원형이 원소스(one source)가 되어 무용의 정체성을 기반으로 한 '멀티유즈(multi use)적 상품의 개발화'라는 독특한 마케팅 시장을 개척할 수가 있는 것이다. 전통춤의 무 관심과 거부라는 춤의 인식적 패러다임을 가치 있는 문 화유산으로 전환함으로써, 춤을 통해 대중의 예술적 정 서를 되찾을 수 있는 전략이 될 것이기 때문이다. 이런 의미에서 문화원형의 전통춤 디지털콘텐츠는 문화 시 민으로써 현 시대가 요구하는 가장 효율적인 방안으로 부각되기 시작한다.

춤이 다양한 영역에서 고부가가치를 실현하고 창작 적 원소스로서 한류의 중요한 문화예술 산업으로 자리 하기 위해서는, 한국문화의 새로운 인식이라는 패러다 임에 부흥하기 위한 방안이 계속해서 실천되어야만 한 다. 그런 의미에서 문화재 전수확대와 교육프로그램, 각 종 시설의 확보를 목표로 하는 정부정책의 변화 과정에 서 미디어의 활용과 상호협동 시스템 구축이라는 융합 과 교류를 통한 문화콘텐츠화는 매우 효과적인 산업 분 야이다.

필자가 작성한 [표 2]를 통해 전통춤을 원형으로 한 디지털 콘텐츠화 내용을 살펴본다.

\section{표 2. 전통춤 문화원형 디지털콘텐츠화}

\begin{tabular}{|c|c|c|c|c|}
\hline 년도 & 콘텐츠 & 내용 & 주소 & 기관 \\
\hline 2007 & $\begin{array}{c}\text { 처용설화의 } \\
\text { 문화원형 } \\
\text { 디지털 } \\
\text { 콘텐츠 }\end{array}$ & $\begin{array}{l}\text { 처용무의 3D 애니메이션 복원 } \\
\text { 과정과 처용설화 스토리의 애 } \\
\text { 니메이션 작업을 통해 디지털 } \\
\text { 콘텐츠화. } \\
\text { 처용설화 문화원형의 콘텐츠 } \\
\text { 개발과정 분석을 통해 다양한 } \\
\text { 문화콘텐츠 작품으로 개발 활 } \\
\text { 용할 수 있는 콘텐츠 상품 가치 } \\
\text { 가 큰 문화원형 소스로 개발. }\end{array}$ & $\begin{array}{l}\text { http://ch } \\
\text { eyongult } \\
\text { ureconte } \\
\text { nt.com }\end{array}$ & $\begin{array}{l}\text { 동의 } \\
\text { 대 학교 } \\
\text { 산악 } \\
\text { 협력단 } \\
\text { (영상 } \\
\text { 미 디어 } \\
\text { 센터) }\end{array}$ \\
\hline 2006 & $\begin{array}{l}\text { 조선시대 } \\
\text { 최고의 } \\
\text { 문화예술 } \\
\text { 기획자 } \\
\text { 효명세자와 } \\
\text { 〈춘앵전〉 } \\
\text { 의 재발견 }\end{array}$ & $\begin{array}{l}\text { 조선조 최고의 문화예술 기획 } \\
\text { 자인 효명세자의 창작정재인 } \\
\text { 〈춘앵전〉을 } 3 D \text { 그래픽, 캐릭 긱 } \\
\text { 터, 3D모션캡처, 게임 애니메 } \\
\text { 이션 소재 및 문화원형 시나리 } \\
\text { 오로 제작. }\end{array}$ & $\begin{array}{l}\text { http://sp } \\
\text { ring.cult } \\
\text { ureconte } \\
\text { nt.com }\end{array}$ & \begin{tabular}{|l}
$($ 주) \\
스페 \\
이스 \\
일루전
\end{tabular} \\
\hline 2005 & $\begin{array}{c}\text { 최승희의 } \\
\text { 문화원형 } \\
\text { 콘텐츠 } \\
\text { 개발 }\end{array}$ & $\begin{array}{l}\text { 최승희 일대기를 조사 분석하 } \\
\text { 여 영상소스로 활용하기 위해 } \\
\text { 초립동, 옥적의 곡, 검무, 보살 } \\
\text { 춤의 모션캡처와 동영상 작업, } \\
\text { 3D 캐릭터를 통해 디지털화. }\end{array}$ & $\begin{array}{l}\text { http://ch } \\
\text { oisunghe } \\
\text { e.culture } \\
\text { content. } \\
\text { com }\end{array}$ & $\begin{array}{l}\text { (주) } \\
\text { 발해 } \\
\text { 게이트 }\end{array}$ \\
\hline 2004 & $\begin{array}{l}\text { 무형문화재 } \\
\text { 로 지정된 } \\
\text { 한국의 춤 } \\
\text { 디지털 } \\
\text { 콘텐츠 } \\
\text { 개발 }\end{array}$ & $\begin{array}{l}\text { 중요문화재로 지정된 살풀이, } \\
\text { 호남류 승무, 처용무, 경기류 } \\
\text { 승무, 진주검무, 태평무, 승전 } \\
\text { 무를 인간문화재의 실연을 통 } \\
\text { 하여 재현하고 디지털 기술을 } \\
\text { 이용하여 텍스트, 비디오, 음악, } \\
\text { 모션캡처, 3D 애니메이션 디지 } \\
\text { 털 콘텐츠로 개발. }\end{array}$ & $\begin{array}{l}\text { http://ko } \\
\text { readanc } \\
\text { e.culture } \\
\text { content. } \\
\text { com }\end{array}$ & (주) \\
\hline 2004 & $\begin{array}{l}\text { 전통놀이와 } \\
\text { 춤에서 } \\
\text { 가장하여 } \\
\text { 등장하는 } \\
\text { 인물의 } \\
\text { 디지털 } \\
\text { 콘텐츠 } \\
\text { 개발 }\end{array}$ & $\begin{array}{l}\text { 굿 놋이 } 33 \text { 종, 농악 잡샛논이 } \\
18 \text { 종, 전통춤 } 2 \text { 종을 선정하여 } \\
\text { 원천자료 조사 및 캐릭터화. } \\
\text { 처용무의 동작을 간결화한 체 } \\
\text { 조를 개발하여 동영상과 교육 } \\
\text { 용 교재로 활용. }\end{array}$ & $\begin{array}{l}\text { http://da } \\
\text { nce.cultu } \\
\text { reconten } \\
\text { t.com }\end{array}$ & $\begin{array}{l}(\text { 주) } \\
\text { 퓨쳐 } \\
\text { 비앤씨 }\end{array}$ \\
\hline 2003 & $\begin{array}{l}\text { 악학궤범을 } \\
\text { 중심으로 } \\
\text { 한 } \\
\text { 조선시대 } \\
\text { 공연문화 } \\
\text { 콘텐츠 } \\
\text { 개발 }\end{array}$ & $\begin{array}{l}\text { 전통악기와 춤, 연주절차, 복식, } \\
\text { 악보와 가사 등을 디지털화하 } \\
\text { 여 사진, 현대화된 텍스트, 샘 } \\
\text { 플링, 2D/3D모션 플래시 애니 } \\
\text { 메이션 등으로 개발. } \\
\text { 조선시대 공연문화를 전시실 } \\
\text { 내용을 토대로 복원, 2D 그래 } \\
\text { 픽 등 '무용이미지' 와 연주 } \\
\text { 형태에 대한 해설과 동영상으 } \\
\text { 로 제공. }\end{array}$ & $\begin{array}{l}\text { http://d- } \\
\text { joseon.c } \\
\text { ultureco } \\
\text { ntent.co } \\
\text { m }\end{array}$ & $\begin{array}{l}\text { (주) } \\
\text { 프라스 } \\
\text { 프로 } \\
\text { 덕션 }\end{array}$ \\
\hline
\end{tabular}

전통춤을 위주로 한 '무형문화재로 지정된 한국의 춤 디지털콘텐츠 개발' 사례는 원형보존을 넘어 한국 춤의 재해석과 활용가치에 대해 재조명하며 춤의 정체성을 일러준다. 춤사위를 사실적으로 제공하고 멀티미디어 기술을 이용하여 춤사위를 재구성, 가공, 창조함으로써 디지털 춤 콘텐츠의 산업적 활용성을 확대한 점이 돋보 인다. 예능보유자들과 전문 춤꾼의 춤사위를 원형에 가 
깝게 기록하고 보존함으로써 전통을 재창조를 통해 가 치 창출이 가능한 측면에서 바라보는 계기가 되었다. 전통유산에 대한 가치를 좀 더 폭넓은 시야로 평가받을 수 있는 계기로 볼 수 있다[13].

전통춤의 정체성 확립 및 재구성의 다양성을 통한 새 로운 가능성은, 디지털 테크놀로지를 통한 춤의 변환과 타 예술영역간의 융합을 통해 대중에게 춤이 보다 친밀 한 패러다임으로 다가가고, 좀 더 밀접한 매체를 통해 다 양한 시각에서 접근할 수 있게 해주는 긍정적 영향이 크 다. 전통춤과 디지털의 결합으로 다양한 콘텐츠 개발과 수요가 증가하면 관련분야의 인력 양성이 늘고 수요 또 한 커져 전공자의 활동범위는 확대될 것으로 기대된다.

그렿다 하더라도 전통춤 콘텐츠에 관한 문화원형 디 지털화는 아직 많은 숙제가 남아 있다. 문화원형콘텐츠 는 문화원형을 소재로, 그 내용을 재분석 및 예술적 의 미를 부여하고, 디지털 기술 $(\mathrm{CT})$ 을 복합.적용시켜 부 가가치를 구현할 수 있도록 제작된 콘텐츠를 말한다. 문화콘텐츠는 이미지, 동영상, 소리, $3 \mathrm{D}$ 등 다양한 유형 의 멀티미디어 콘텐츠로 구성되며, 다양한 매체로의 변 환 제작이 가능한 확장성이 요구된다. 따라서 문화원형 창작소재는 콘텐츠를 개발하기 위해 사용되는 일체의 자원을 총칭하는 것으로, 콘텐츠 산업의 상상력과 창의 력의 원천이 되는 소재를 일컫는다[14]. 향후 관련 산업 분야의 부가가치 창출을 위한 소재로서 산업적 성격이 강하다,

즉 문화원형의 디지털콘텐츠는 자료정보로서의 '디 지털화'를 넘어서 정보를 통해 새로운 부가가치를 창출 할 수 있는 상상력과 창의력의 원천을 제공해야 한다는 것이다. 전통춤 문화원형 또한 자원에 대한 기록을 나 열하는데 그쳐서는 안 된다. 전통춤 원천 소스 하나하 나에 시각적, 청각적 이미지와 같은 오감을 충족할 수 있는, 창의력을 불러일으킬 수 있는 방안을 고려해야 한다는 뜻이다. 이 점에서 지금까지의 춤 원형의 동영 상, 음악, 캐릭터, 플래쉬 애니메이션, 3D애니메이션 작 업은 다차원적 노력에도 불구하고 콘텐츠화의 원래의 목적에 비추어 몇 가지 활용방안에 대한 추가 검토가 필요하다. [표 3]은 전통춤 콘텐츠의 의도와 기대효과의 활용방안에 대해 간략하게나마 검토해본 것이다.
표 3 전통춤 콘텐츠의 활용방안과 가치 검토

\begin{tabular}{|c|c|c|c|}
\hline \multirow[b]{2}{*}{$\begin{array}{l}\text { 넌 } \\
\text { 도 }\end{array}$} & \multicolumn{3}{|c|}{ 과제 } \\
\hline & 기획의도 & $\begin{array}{c}\text { 개발내용 및 } \\
\text { 기대효과 }\end{array}$ & 활용방안의 검토 \\
\hline & \multicolumn{3}{|c|}{ 처용설화의 문화원형 디지털 콘텐츠 } \\
\hline $\begin{array}{l}2 \\
0 \\
0 \\
6\end{array}$ & $\begin{array}{l}\text { 궁중정재인 효명 } \\
\text { 세자와 춘앵전의 } \\
\text { 문화 예술적 가치 } \\
\text { 를 선전. } \\
\text { 한국 궁중정재의 } \\
\text { 아름다움과 가치 } \\
\text { 를 재조명. }\end{array}$ & $\begin{array}{l}\text { 콘텐츠 구성은 시나 } \\
\text { 리오, 효명세자, 춘 } \\
\text { 앵전, 궁중정재로 구 } \\
\text { 분. } \\
\text { 기획의도, 등장인물 } \\
\text { 과 사건 등이 텍스트 } \\
\text { 와 이미지화로 담김. } \\
\text { 춘앵전은 문헌, 도 } \\
\text { 상, 복식, 무보, 연표 } \\
\text { 자료와 디지털 복원 } \\
\text { 이미지 포함 }\end{array}$ & $\begin{array}{l}\text { ㅊㅓㅓ저한 고증을 거친 후 } \\
\text { 춤을 교육,산업용으로 } \\
\text { 개발. } \\
\text { - 여기에 스토리텔링 기법 } \\
\text { 을 동원해 새롭게 시나 } \\
\text { 리오를 구성한다면 '대 } \\
\text { 장금 처럼 한류 문화콘 } \\
\text { 텐츠로 활용할 수도 있 } \\
\text { 음. }\end{array}$ \\
\hline $\begin{array}{l}2 \\
0 \\
0 \\
5\end{array}$ & $\begin{array}{l} \\
\text { ·최승희의 고향인 } \\
\text { 홍천군과 연계해 } \\
\text { 지역 관광자원 개 } \\
\text { 발 및 해외 관광 } \\
\text { 객 유치. } \\
\text { · 남북한 동질감 회 } \\
\text { 복과 동북아평화 } \\
\text { 공동체 건설 소재 } \\
\text { 로의 '최승희' } \\
\text { 문화 콘텐츠 발 } \\
\text { 굴. }\end{array}$ & 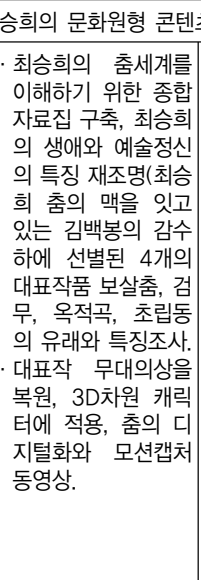 & $\begin{array}{l}\text { 개발 } \\
\text { · 전통춤의 특징이 기술적 } \\
\text { 결함으로 결여됟전통 } \\
\text { 춤과 복식은 밀접한 연 } \\
\text { 관. 캐릭터 의상 대부분 } \\
\text { 이 밀착된 혛태. 전통춤 } \\
\text { 사위의 예술적 형상화에 } \\
\text { 대해 더 고민할 필요성. } \\
\text { · 초립동 두루마기 길이가 } \\
\text { 지나치게 짦고 ‘옥적의 } \\
\text { 곡' 에 등장하는 바지는 } \\
\text { 실제로는 치마였음. } \\
\text { 검무에서 쾌자도 실제보 } \\
\text { 다 짧음. } \\
\text { · 보살춤에서는 장식 베일 } \\
\text { 을 복원영상에 포함시키 } \\
\text { 지 않았음, 곧 콘텐츠의 } \\
\text { 신뢰성과 고증성에 대해 } \\
\text { 역사적 사명감이 부각되 } \\
\text { 어야 할 필요성 제기. }\end{array}$ \\
\hline $\begin{array}{l}2 \\
0 \\
0\end{array}$ & $\begin{array}{l}\text {. 한국춤에 관한 최 } \\
\text { 고자료 공간화. } \\
\text { 한국춤에 대한 고 } \\
\text { 증된 데이터 개발 } \\
\text { (무형문화재 지정 } \\
\text { 보유자 및 학계 } \\
\text { 권위자를 통한 고 } \\
\text { 증 및 자문). } \\
\text { 산업적으로 황용 } \\
\text { 할 수 있는 문화 } \\
\text { 콘텐츠 개발(모션 } \\
\text { 켑처의 세분화, } \\
\text { 디테일, 캐릭터 } \\
\text { 등 춤사위 자료 } \\
\text { 확보). } \\
\text { 한국춤을 대표하 } \\
\text { 는 문화 아이콘으 } \\
\text { 로서의 가치창조. } \\
\text { 춤 전승 예능인의 } \\
\text { 춤동작별 모션켐 } \\
\text { 처- 무형문화재 } \\
\text { 보유자 또는 전수 } \\
\text { 관에 연계해 춤 } \\
\text { 원형 복원. }\end{array}$ & 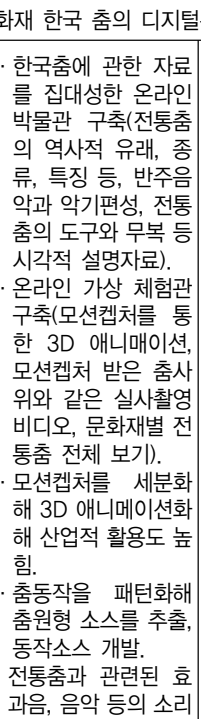 & $\begin{array}{l}\text { 콘텐츠 요소가 다양한 } \\
\text { 게임개발에 원천 소스로 } \\
\text { 활용되기에 충분한가. } \\
\text { 창의적인 재창작화를 통 } \\
\text { 해 가공된 디지털 콘텐 } \\
\text { 츠가 고부가 가치산업 } \\
\text { 부문(다큐멘터리, 영화, } \\
\text { 애니메이션)에 활용되 } \\
\text { 기에 비주ㅇㅓㅓ한 요소가 } \\
\text { 다소 부족하지 않았는가 } \\
\text { - 복원의 기록적 차원에 } \\
\text { 그친 인상. } \\
\text { 한국춤 원형자료를 통해 } \\
\text { 한국예술의 정체성의 근 } \\
\text { 원을 찾는데 적절했는 } \\
\text { 가. } \\
\text { 자료의 사후 검증과 기 } \\
\text { 대효과 창출에 관한 시 } \\
\text { 스템을 효율적으로 점검 } \\
\text { 할 수 있는 프로그램은 } \\
\text { 개발할 수 없는가. } \\
\text { 원천 소스로 활용될 요 } \\
\text { 소는 무엇인가- 대중적 } \\
\text { 활용 방안 등을 검토할 }\end{array}$ \\
\hline
\end{tabular}




\begin{tabular}{|c|c|c|c|}
\hline & & 자료 작성. & $\begin{array}{l}\text { 필요성. } \\
\text {. 무형문화재로 지정할만 } \\
\text { 한가-한국을 대표할만 } \\
\text { 한 예술로, 재창작시 비 } \\
\text { 주ㅇㅓㅓ한 요소를 충분히 } \\
\text { 반영했는가. } \\
\text { 전통춤과 관련된 효과 } \\
\text { 음, 음악 등의 관련학적 } \\
\text { 이롲지침 및 교육적, 산 } \\
\text { 업적 원천 자료로 활용 } \\
\text { 하는 방안에 대해 충분 } \\
\text { 한 고려가 있었는가. }\end{array}$ \\
\hline & \multicolumn{3}{|c|}{ 전통놀이와 춤에서 가장하여 등장하는 인물의 디지털콘텐츠 개발 } \\
\hline $\begin{array}{l}2 \\
0 \\
0 \\
4\end{array}$ & $\begin{array}{l}\text { - 전통놀이와 춤에 } \\
\text { 등장하는 인물의 } \\
\text { 캐릭터를 개발. } \\
\text { · 창작의 기본 데이 } \\
\text { 터로 활용하도록 } \\
\text { 분야별 시놉시스 } \\
\text { 를 개발. } \\
\text { · 처용무의 춤동작 } \\
\text { 을 응용하여 전신 } \\
\text { 체조 교재 개발. }\end{array}$ & $\begin{array}{l}\text { · 전통놀이와 춤 항목 } \\
\text { 별 정의, 역사, 종류 } \\
\text { 등을 텍스트로 제공. } \\
\text { 전통놀이(굿놀이, 잡 } \\
\text { 색놀이)와 춥(학무, } \\
\text { 처용무)을 분류하여 } \\
\text { 인물의 사진과 재담 } \\
\text { 및 연행 내용을 제 } \\
\text { 공. } \\
\text { 디지털화된 전통놀 } \\
\text { 이와 춤은 사진과 동 } \\
\text { 영상자료를 기반으 } \\
\text { 로 } 2 \mathrm{D}(2 \mathrm{D} \text { 마당, } 2 \mathrm{D} \\
\text { 캐릭터)와 원형캐릭 } \\
\text { 터가 비교 가능. } \\
\text { 이는 } 3 \mathrm{D} \text { 응용에 관 } \\
\text { 한 캐릭터를 제공, } \\
\text { 춤(처용무) 동작을 } \\
\text { 응용한 체조 등이 개 } \\
\text { 발 가능. }\end{array}$ & $\begin{array}{l}\text { · ‘처용무’ 의 다양한 춤 } \\
\text { 사위를 캐릭터화해 적극 } \\
\text { 적인 활용방안을 검토한 } \\
\text { 성과. } \\
\text {. 캐릭터가 특정부분만 과 } \\
\text { 장해 창작적 응용 소재 } \\
\text { 로 활용하기에 상상력을 } \\
\text { 주는가. } \\
\text { - 처용무를 활용한 체조동 } \\
\text { 작은 전통춤을 교육용 } \\
\text { 활용방안으로 구체화한 } \\
\text { 좋은 본보기. }\end{array}$ \\
\hline \multirow[b]{2}{*}{$\begin{array}{l}2 \\
0 \\
0 \\
3\end{array}$} & \multicolumn{3}{|c|}{ 악학궤범을 중심으로 한 조선시대 공연문화 콘텐츠 개발 } \\
\hline & $\begin{array}{l}\text { - 도설로 되어 있는 } \\
\text { 악학궤범을 디지 } \\
\text { 털화해 조선시대 } \\
\text { 공연문화를 재현. }\end{array}$ & $\begin{array}{l}\text { ·무용감상실에는 연 } \\
\text { 향무(정재) 21종과 } \\
\text { 제례무(일무) 4종을 } \\
\text { 콘텐츠로 개발. } \\
\text {. 원천자료의 이미지 } \\
\text { 와 2D 그래픽 복원 } \\
\text { 이미지를 제공. }\end{array}$ & $\begin{array}{l}\text {. 악기, 복식, 의물의 복원 } \\
\text { 과 연주시 무용배치도와 } \\
\text { 연주 형태에 대한 고증 } \\
\text { 을 철저한 편. } \\
\text { · 콘텐츠 활용방안은 기초 } \\
\text { 적인 수준으로 동영상 } \\
\text { 연구가 활발히 진행 되 } \\
\text { 어야 할 필요. } \\
\text { · 콘텐츠 원형자료가 상업 } \\
\text { 적 판매를 통해 부가가 } \\
\text { 치를 높일 수 있는 방안 } \\
\text { 이 검토되어야 할 것. }\end{array}$ \\
\hline
\end{tabular}

춤원형 과제는 2002 년 민족미학연구소의 콘텐츠 개 발인 '탈의 다차원적 접근을 통한 인물유형 캐릭터 개 발' 에서 탈과 춤의 다차원적 접근을 통한 동영상, 음악, 캐릭터, 플래쉬 애니메이션, $3 \mathrm{D}$ 애니메이션 작업이 이루 어지기 시작한다. 그러나 전통춤만을 위한 개발은 위의 5 가지 과제가 주목할 만한 것이었고 타 분야에 비해 미 미한 편이다.

또한 위의 표에서도 알 수 있듯이 고증의 신뢰성이나 춤 콘텐츠 개발이 고부가 가치를 어떻게 창출할 수 있 는가 하는 측면에서 더욱 연구를 거듭할 필요가 있다고 본다. 춤의 스토리텔링 개발이나 애니메이션을 위한 캐
릭터의 특징 등은 무궁무진한 데 비하여, 춤의 기록적 인 설명이나 단순한 움직임의 묘사를 통한 고고사적 재 현에 치중하고 있다. 즉 춤사위마다 나타나는 고유성, 호흡과 움직임과의 연계성, 복식과 상호 밀접한 관련이 미치는 춤사위의 선(線), 해학성이 깃든 한국 춤의 정서 를 이해하기 위한 원천 소스로는 아직 멀게만 느껴진 다. 한국 전통춤은 로봇과 같은 감성이 배제된 움직임 만으로는 설명되어질 수도 없을뿐더러, 한국춤만의 독 창성을 헤아릴 수 없다. 손끝과 발끝이 호흡으로 전달 되는 원리, 장삼과 수건을 뿌릴 때 나타나는 여백의 미 룰 설명하려면 예술로서 춤의 특징을 이해할 수 있도록 춤의 콘텐츠화가 이뤄져야 한다.

이러한 점으로 볼 때 춤 원형의 디지털화는 문화적인 감수성을 야기 시킬 수 있는 궁극적인 원천 자료의 제 공을 위해 전문 인력의 양성과 학문적 융합 시스템이 우선으로 보인다. 기록의 디지털화에 앞서 한국 전통춤 의 고유한 미에 대해 깊이 이해하고 춤을 예술로 보여 줄 수 있는 시각화된 기술로서 춤의 영역을 구분해야 할 필요가 있다.

전통춤을 상품화하여 부가가치를 올린다는 것은 한 국 예술의 우수성을 누구나가 이해해야 하는 보편적 인 식이 필요하다. 한국 전통춤의 무궁한 창조적 계승에 필요한 디지털콘텐츠화는 한국예술을 장르마다 깊이 있는 범주에서 보고, 예술적 시각으로 대중적인 가치인 식과 보편적 세계화의 실현 등이 우선적인 과제로 떠오 른다.

\section{III. 전통춤 문화원형 디지털콘텐츠의 정책 활용 방안}

문화예술과 관련된 문화정책은 문화행정, 예술행정, 예술경영 등과 유사한 의미로 사용되고 있지만, 그에 대해 합의된 개념규정은 아직 없는 실정이다. 이에 대 한 공식적인 개념규정은 1967년 모나코에서 개최된 유 네스코 주최 '문화 정책에 관한 원탁회의 보고서'에서 처음 확인된다. 여기에서는 문화정책을 '주어진 시간 내 에 사회에 적응할 수 있는 모든 인적자원의 효용성에 
따라 어떤 특정한 문화적 필요성에 부응할 수 있도록 한 행위에 대한 총체를 의미'하는 것으로 파악하고 있 다. 하지만 일반적으로는 문화 활동과 관련체계의 장기 적인 목표와 중·단기적인 목표 그리고 인적·재정적·법 률 제도의 총체라는 개념으로 받아들이기도 한다[15]. 이러한 개념을 유럽회의에서는 문화정책을 '문화와 관련된 중앙정부, 지방정부, 기타 공공기관 등 공공부문 행동수단의 총체적인 틀(public measures)'로 이해하고 정책목표 달성을 위한 계획, 집행, 평가 기제가 필요하 다고 제시한 바 있다[16].전통적으로 문화를 예술과 동 일시되는 관점에서 볼 때 문화예술정책에는 춤도 포함 된다. 문화예술정책의 일환에는 춤 예술을 위한 재정지 원 정책이 있고 춤에 관한 모든 문화일반에 관해 국민 에게 동일한 기회를 주게 만드는 공공의 서비스라는 관 점이 부각될 수 있을 것이다.

1980년대 문화정책은 '문화정체성 확립'외에 '문화향 수 확대를 위한 기반 마련', '문화예술 창작의 활성화’를 중요한 목표로 설정하였다. 문화정책 대상을 예술부문 에서 국민전체로, 중앙의 문화에서 지역문화로 확대시 켰다[17]. 그럼에도 예술정책은 중앙집권적인 문화행정 체계를 중심으로 이루어졌고, 지방단체의 자발적인 노 력은 미흡해 왔다. 지자체의 예산으로 수도 없는 지역 축제가 활성화 되었다 하더라도, 전통춤 예술분야의 원 형보존과 계승 발전적 차원, 대중적 인식은 아직도 부 족한 단계에 있다. 원소스one source에 대한 정확한 고 증을 필요로 하는 원형 보존적 자세나 홍보 인력의 부 족, 문화 산업으로서의 가치 인식 등을 들 수 있다. 집 권세력의 정치적 성향이 진보냐, 보수냐에 따라 정책방 향이 다르게 설정되고 있는 측면을 알 수 있다. 독재정 권 유지를 위해 반공이데올로기를 강조한 정책이 만화 애니메이션에 강력한 영향을 미친 사례를 통해 이를 짐 작해볼 수 있다[18].

이러한 정책 가운데 하나로 전통춤 디지털콘텐츠의 개발은 아직 기초가 부족한 골절에서 상품을 포장하는 듯 해 보인다. 전통춤의 고부가가치는 인문학적 역사 콘텐츠와 융합되어 무한한 창작의 소재가 되기에 충분 하다 이를 위해서는 디지털 문화콘텐츠의 무궁한 가치 를 재조명해 보며 현재의 문제점으로부터 문화정책의 나아가야 할 방안을 모색해 보기로 한다.

\section{1. 문화원형의 디지털 컨버전스 Digital Convergence}

디지털 컨버전스란 디지털 융합이라는 뜻으로, 하나 의 기기와 서비스에 모든 디지털 기술을 묶는 새로운 형태의 융합을 말한다. 이러한 현상은 유선과 무선의 통합, 통신과 방송의 융합, 온라인과 오프라인의 결합 등으로 이루어진다. 디지털과 기기, 서비스의 융합 현상 은 현재 한국의 경제구조를 변화시키고 나아가 사회구 조 및 산업 구조를 급속하게 변화시키고 있다.

디지털 컨버전스 시대의 큰 특징은 콘텐츠의 디지털 화다. 춤 콘텐츠의 서비스가 대중이 이용할 수 있도록 디지털화된 서비스를 제공하게 됨으로써 강한 확산으 로 빠른 전달과 홍보효과를 가져온다는 점이다. 원형의 콘텐츠는 현실에서 이용할 뿐만 아니라 가상현실에서 도 활용이 가능해 졌다. 가상현실 및 $3 \mathrm{D}$ 입체 등은 급속 하게 변화하는 산업구조에서 문화원형이 문화산업으로 서의 가치를 활발하게 창조해 낸다. 디지털 컨버전스는 공급자와 소비자가 구분되어 있는 것이 아니라, 소비자 도 생산에 참여하고 마케팅을 하는 등 융합형 소비자의 개념이 생겨났다. 즉 소비의 주체가 따로 있는 것이 아 니라 역할 구분이 없이 넘쳐나는 지식과 그 생산물을 서로 교류하기에 이른다.

이에 문화원형 디지털콘텐츠 사업 또한 정부 주도에 서 벗어나 전문가나 민간 주도에 의한 원천자료의 연구 가 확대되어야 한다. 이러한 관심과 수요를 위해 일반 사용자들에 의한 융합형 상품 가치와 소비의 확산을 위 한 정책도 마련되어야만 한다. 한편 이를 실현하기 위 해서는 문화원형의 창작소재 개발에 관한 철저한 고증 과 검토도 중요한 문제로 대두된다.

전통춤 문화원형의 콘텐츠 사업에서 여실히 드러나 는 문제는 단연 콘텐츠의 고증성이었다. 디지털화의 기 술적인 문제 이전에 기초적인 토대를 제대로 정비해야 만 하는 신뢰성의 문제다. 최승희 춤의 복원에 있어서 도 그 문제는 여실히 드러난다. 최승희 춤에서 중요한 복식이나 움직임, 예술로서의 미를 전달하기 위한 원형 의 소스에 대해 기술적인 문제의 한계로 변명하는 것 은, 전통춤 원형의 원천소스 제공과 관련한 핵심을 간 과하는 일이다. 현재 사극에 방영되는 드라마 속 전통 
춤에서도 그러한 문제는 어제오늘의 일이 아니다. 원천 적인 디지털 소스를 정확하게 제공하고 나서 그로 인한 창작의 아이디어에 살을 더해야만 한다. 자칫하면 전통 예술의 정체성에 혼란이 오고 전통춤에 관한 이해의 패 러다임까지 바꾸어 버릴 수 있기 때문이다.

디지털 컨버전스의 차원에서 이러한 문제를 해결하 기 위해서는 인력의 양성과 인접 학문간 기초연구가 정 책적으로 마련되어져야만 한다. 그 분야의 전문 인력 양성 위주에서 문화산업의 리더로서 타 분야와의 융합 및 기술력의 연계를 위한 인력 양성을 의미한다. 이를 위해서는 산·학.연의 문화원형 거버넌스(Governance) 구축마련이 실현되어야 한다.

많은 학계와 산업계, 연구기관, 정책기관에서는 문화 원형의 디지털화가 문화산업의 고부가가치를 창조할 수 있는 지름길임을 실감하고 있다. 문화원형의 디지털 화 사업은 각 분야의 전문가와 산학단이 주도적인 역할 을 하고 그러한 연구기관에 아낌없는 정책적 지원이 우 선시되어야만 한다. 전통문화진흥을 담당하는 행정에 서는 공모 작품을 선정하고 시상하여 게임이나 애니메 이션, 광고 기획이나 제작 회사에게 소재를 활용할 수 있는 기회를 제공하여 주고, 대중의 참여 사업을 홈페 이지에 뱅크화하여 보다 많은 관심과 수준 놓은 아이디 어를 얻기 위해 대중에게 서비스 할 필요가 있다. 그러 나 현재 문화원형 공모사업은 각종 저작권의 문제와 일 반 기업의 문화산업의 가치인식 부재에 의해 전폭적인 지원이 이루어지지 않은 실정이다.

우선은 문화원형의 콘텐츠가 당장의 수입을 올릴 수 없는 기초적인 원천 자료이기 때문이기도 하다. 이를 위해서는 정부기관이나 정책기관이 민간후원 제도를 마련하고 기업의 메세나(Mecenat) 운동을 선도할 필요 가 있다[19].

문화원형디지털화는 사업의 성격상 초기투자를 확보 하기 어렵다. 이 점에서 문화정책과 문화산업정책은 차 이를 보인다. 즉 문화정책은 문화의 기본적 주체인 개 개인을 핵심으로 하는 자발적-자주적인 동시에 개인이 나 단체 등의 활동만으로 제약이 따를 수밖에 없는 점 을 보완하고 지원하며, 사회전체적인 관점에서 문화의 학습·창조·전달·향수·축적·교류 등의 활동이 원활하게 이루어지도록 조건과 기반을 정비하는 것을 기본으로
한다. 반면 문화산업정책은 보편적으로 산업의 구조, 행 동, 성과에 중요한 영향을 주는 것을 직접적인 목적으 로 하는 정부의 정책이라고 할 수 있다. 이는 실적으로 는 정부가 추구하는 목적에 따라 특정산업의 육성을 위 한 정책을 의미한다[20].

지속적인 인문학의 연구가 요구되는 상황에서 디지 털화 사업을 추진하고 문화산업의 창작기반으로 역할 을 수행하기 위한 문화원형 거버넌스의 구축은 현재 정 부주도의 사업을 민간주도의 사업으로 확대 변화해 나 아가야 한다. 민간의 역할을 활성화하고 예산의 투자방 향을 결정해야 한다. 학계와 산업계를 우선으로 정부는 정책을 실현해야 한다. 흥미를 끌만한 소재를 민간 중 심에서 공모하고 민간이 추진하기 어려운 기초분야연 구에 대해 더 집중적인 정부지원을 해야만 한다.

산만하고 신뢰가 부족한 고증에 관해서는 저작권을 통해 산학의 책임을 짊어주고, 검증된 원형자료에 대해 서는 정부중심의 콘텐츠 무료개방을 통해 창작 자원화 에 대한 자발적인 흥미를 유발해야 한다. 즉 정부의 문 화정책은 거시적으로 공공의 국면에서 정책적 저작권 의 무료화를 위한 나름의 투자를 시행할 필요가 있으 며, 산업적 콘텐츠에 관해서는 문화산업정책의 일환에 서 그에 관한 저작권을 민간 투자기업이나 산학단으로 이전함으로써 간접적인 정부주도의 산학을 위한 저작 권 시스템 마련이 필요하다.

이러한 거버넌스 구축은 단기적으로 기초 원형 소스 의 인문학적 콘텐츠 디지털화를 선도하고, 장기적으로 는 믿고 신뢰할 수 있으며 문화상품으로의 OSMU (One-Source Multi-Use)를 극대화 할 수 있을 것이다. 춤 문화원형에 있어서도 이를 위한 노력으로 문화원 형 디지털화의 단순한 성과물 외에도 2 차 콘텐츠 개발 의지를 계속적으로 고취할 수 있는 지원제도가 함께 병 행되어야 한다. 춤 전문교육과정에서 문화콘텐츠 관련 교과의 개설도 중요하지만 콘텐츠 관련학과와의 연계 교육을 통해 기술적인 콘텐츠 개발의 심화 협동교육 체 계를 마련해야 한다.

즉 $\mathrm{CT}$ (Culture Technology)의 상품가치를 창출하는 문화상품이 되기 위해서는 타 분야의 교류와 융합, 복 합적인 학문의 틀이 정책과 더불어 병행되어야 할 사항 이다. 공동 세미나나 워크샵 및 심포지엄의 활성화도 
중요한 반면, 학술진흥재단과 같은 기관에서의 학제간 융합과제 지원 모색이 정부산업정책에 맞물려 원활한 소통을 진행할 수 있어야 한다.

예를 들면 학술진흥재단의 과제가 단순한 예산지원 정책의 한 일환으로 자료의 축적 현상으로 나타날 것이 아니라, 정부기관 정책의 공공성에 부합되는 개방된 학 술자료를 통해 누구나 참여하는 열린 공간으로 디지털 화 될 필요가 있다. 즉 대규모 그룹이나 선행연구 기관 에 우선을 둔 과제지원정책을 넘어서고 참여하는 민간 시스템도 함께 구축되어야만 한다. 산학협력단을 통한 투자 외에도 소규모 민간 기업이 우수한 인재를 양성하 는 시스템 방안은 보다 공공적인 정책으로 나아가는 방 향이 될 것이다. 무궁한 아이디어 개발 전략은 춤 원형 의 흥미로운 스토리텔링storytelling이나 애니메이션 캐 릭터 등 소비자의 욕구를 충족시킬 수 있는 창조의 원 천으로, 거듭 기관의 원천 자료의 무료 개방이 더욱 확 대 되어야 함을 의미한다. 이에 장기적으로 원천 자료 의 상품화를 위해서도 현 시점에서는 다양한 정보를 제 공할 필요가 있다.

\section{2. 지역춤의 소통 - 글로컬라이제이션}

위의 문화원형 거버넌스 정책을 아무리 강조하고 있 다하더라도 전통춤에 관한한 문화원형의 상품가치에 대한 인식은 아직 터무니없이 부족하다. 이를 위해서는 전통춤 문화원형의 가치 재조명과 문화적 정체성에 대 한 대중화 정책마련이 필요하다고 볼 수 있다.

춤은 연희되고 즐기기 위한 것도 있지만, 문화적 감 수성과 의식의 결정체로 가장 한국적인 부가가치로 존 재한다는 인식을 의미한다. 지역축제의 활성화에도 불 구하고 전통춤은 단순한 유희적인 오락물이나 축제의 흥을 돋우기 위한 의례적인 행사로 비춰진다. 따라서 전통춤을 보더라도 춤에 대한 바른 홍보나 가치 인식의 토대는 구축되어 있지 못한 실정이다.

그렇다 하더라도 많은 지역축제는 그 지역의 춤과 놀 이를 계승하고 보다 많은 사람들에게 알리기 위한 문화 적 홍보물로 활성화 되는 계기를 마련하고 있다. 천안 의 흥타령 축제나 안성의 바우덕이 축제는 춤과 놀이를 테마로 매년 대회를 개최하여 지역의 놀이문화를 축제
에서 선보인다. 당연히 금산의 인삼처럼, 그 지역에는 어떠한 놀이가 유래되고 어떠한 춤을 즐겨 췄는지 정도 는 자연스럽게 인식될 수 있다. 그러나 우리의 전통춤 이 세계적인 상품으로서의 충분한 가치를 인식하기에 제도마련이나 홍보책, 교육 프로그램 등에서는 미흡하 다. 이러한 실정에서 콘텐츠 개발이라는 상품 전략은 대중에게는 당연히 낮설기만 할 것이다. 그러므로 전통 춤 콘텐츠의 다양한 창조적 아이디어를 이끌기 위해서 는 대중적인 홍보와 마케팅 전략이 대두된다. 즉 이러 한 전략은 '글로컬라이제이션(glocalization)'의 정의를 들어 설명할 수 있다.

글로컬라이제이션은 글로벌global과 로컬local의 결 합어로 경영, 마케팅 분야에서는 국제적 사업의 산물과 조직을 지역 상황에 맞추는 것을 의미한다. 세계화를 추구하면서 동시에 현지 국가의 기업풍토를 존중하는 경영방식을 뜻한다[21]. 즉 글로벌화를 주장하는 모든 가치에서 지역 가치의 개별성을 존중하고 소통의 중요 성을 의미하는 말이기도 하다. '가장 한국적인 것이 세 계적인 것이다’라는 말하고도 일맥상통한다.

최근 글로벌리즘이 확대되면서 로컬리즘의 중요성이 부각된 지도 꽤 되었다. 하지만 문화콘텐츠, 특히 예술 장르에서 우리 전통문화의 고 부가가치에 대해 주목하 기 시작한 것은 영화와 드라마가 계기가 된 것으로 극 히 최근의 일이다. 임권택의 영화 서편제는 전통예술인 판소리에 대한 대중의 관심을 크게 높여주었고, 송승헌 이 기획한 난타 공연은 사물놀이의 붐을 일으켰다. 이 는 영상과 공연의 첨단 문화산업의 접목이 대중에게 전 통문화에 대한 관심과 이해에 시너지 효과를 미치는 것 을 보여준 예이다. 최근 한류가 세계적인 문화상품으로 각광받는 것은 한국문화의 세계화를 뜻하는 것이자 지 역성과 개별성, 특수성 속의 보편성을 상징적으로 보여 준다. 이는 전통의 원형 콘텐츠에 커다란 숙제를 안겨주 는 핵심이다. 한 때 서구문화를 수용하면서 전통문화에 대한 홀대와 무관심이 자긍심으로 바뀌게 되면서 무엇 이 우리 고유의 정체성인가에 대해 누구나 알아야 할 때 가 온 것이다. 그리고 선진문화에서와 같이 무궁무진한 우리 고유 놀이와 춤에 대한 정부정책이 간접적인 후견 인으로 물러나기 위해서는, 대중이 문화를 인식하고 이 끌어 낼만한 제도적 장치마련을 해 주어야만 한다. 
글로컬라이제이션을 위한 방안은 무엇보다 '문화의 대중화'일 것이다. 대중화는 엄밀히 대중 행동양식의 획 일화, 일종의 유행과 같은 것이고 널리 퍼져 친숙하고 그렇게 되는 보편성을 의미한다. 이런 의미에서 지역축 제 마케팅은 기초적인 문화예술의 상품화전략으로 충 분하다. 다만 전통춤을 대중에게 알리기 위해서는 그에 맞는 상품화 전략이 지자체에 그칠 것이 아니라, 정부 기관이나 문화예술단체의 교류 속에서 많은 자료들을 공유하고 실천해 나아가는 방법을 도모할 필요가 있다. 천안의 흥타령 축제에서 매년 선보이는 전국 춤 경연 대회는 지역축제가 채택한 매우 훌륭한 전략이라고 하 겠다. 천안의 지역축제를 활성화하여 경제적 이익을 창 출하는 것 외에 전국적 기량의 선보일 수 있는 무대인 까닭이다. 천안 흥타령축제의 춤 경연 대회는 춤에 대 한 관심을 불러일으킨 점과, 춤을 상품화하는 마케팅 전략 측면에서 성공한 것으로 볼 수 있다. 또한 같은 전 통춤이라고 해도 매년 공연 프로그램을 똑같이 할 수는 없기에 다양한 춤을 선보임으로써, 전통춤마다 무궁한 원천적 요소를 끄집어내어 자연스럽게 창작미를 가미 하고 있다. 그것은 곧 지역성을 살린 춤이 예술적으로 평가 받을 수 있고, 외국인은 물론 서로의 소통을 통해 춤이 관광자원으로 유입되는 것을 뜻한다. 이를 위해서 는 정책적 홍보는 물론이고 쉽게 대중에게 접근할 수 있는 스토리텔링이 중요하다.

위의 효명세자와 춘앵무, 처용무의 원형과제 경우에 도 스토리텔링은 춤을 이해하는데 효과적인 전달방법 이다. 처용무의 다섯 캐릭터(청, 흑, 황, 백, 홍)가 마치 어린이들이 열광하는 캐릭터 텔레토비나 뽀로로처럼 애니매이션에 적용되어 세계 곳곳을 방문하는 유명인 사로 자리매김 할 수 있다.

이처럼 문화원형은 고유성과 더불어 인류의 공동 유 산으로서 보편성도 동시에 가지고 있다. 즉 개별적 고 유성과 동시에 인류의 집단 무의식, 공통적 경험과 교 류를 포함한 역사적 조건 등의 이유로 보편적 가치가 존재한다[22]. 전통춤은 독창적인 우리 문화원형인 동 시에 세계적인 글로벌 문화원형이 될 수 있다. 여기에 보편적 틀의 개념을 더한다면 문화콘텐츠의 우리 문화 원형은 '문화의 보편적이며 고유한 특징을 나타내는 본 디모습인 동시에 이를 활용, 발전시킬 수 있는 보편적
방식의 틀'을 의미한다[23].

전통춤 원형의 복원은 앞서 강조하듯, 제대로 된 고 증과 신뢰를 바탕으로 하여 매체를 통한 사회적 확산으 로 더욱 더 많은 콘텐츠를 생산할 수 있다. 이를 위해서 는 쉬운 이야기와 창작의 소재를 제공할 만한 다양한 시도가 필요하다. 춤 원형의 역사적 사실을 그대로 $\mathrm{DB}$ 화하는 것은 자칫 역사적인 진부함으로 흥미를 유도하 기 어렵다. 춤 콘텐츠를 스토리텔링화한 다큐멘터리, 전 통춤을 원형으로 하여 만든 UCC 홍보물, 춤 캐릭터가 안내하는 공연관람 등은 대중에게 보다 친숙한 이미지 로 한 발 더 자연스럽게 다가갈 수 있는 매체로 작용될 것이다.

\section{3. 춤 컨텐츠의 MSMU화 - 커뮤니티 아트 시스템 구축}

문화관광부는 2006년 '창조', '소통', '나눔’ 등 문화행 정의 3 대 가치를 예술분야로 확산했다. 이는 문화예술 의 대중 참여를 유도하고 문화시민으로 정착하기 위한 문화정책이라 할 수 있다.

영국의 경우 1975년 영국예술위원회 내부에 '커뮤니 티 아트 위원회(Community Arts Committe')를 설립하 고, 국가적인 차원에서 커뮤니티 아트를 촉진하기 위한 지원 결정의 권고문을 발표했다. 이 권고문 내용의 일 부는 다음과 같다.

"현재 예술을 즐기고 경험하는 사람은 인구의 약 $5 \%$ 정도 된다. 이는 대중들의 기존 예술에 대한 접근하 기 어려움, 즉 기존 예술의 배타성 때문이라 생각되 며, 이 결과 다수의 사람들이 그들의 삶과 질을 높여 나갈 권리에서 소외되고 있다. 기존 예술의 배타성 과는 달리 커뮤니티 아트는, 예술이 일상적인 삶과 관계가 없고 거리가 있다는 생각을 없애, 사회에서 문화의 근본적인 역할을 환기시켜 보다 많은 사람들 에게 예술에 참여할 기회를 제공해 주고 있다[24]."

이후 영국은 커뮤니티 아트 활동을 연간 250,000파운 드 규모로 지원하기 시작하였고, 1990년대 중반 이후에 는 그 규모가 크게 늘어나게 되었다. 이러한 커뮤니티 
예술 활동은 사회 통합적 역할에 크게 이바지 하게 되어 예술의 효용성을 인정받게 되면서 문화민주주의 정책이 라는 용어로 점차 유럽전역으로 확대되기 시작한다.

커뮤니티(Community)라는 '공동체'는 구성원들 간 심정적, 정신적 일체감 또는 이해관계의 동질성에 근거 하여 자발적으로 조직된 소집단'이라는 의미를 갖는다 [25]. 따라서 커뮤니티 아트의 개념에는 공동체의 구성 원이 직접 예술에 참여하거나 예술가와 협업하여 적극 적인 공동체 활동을 확대하기 위한 문화적 활동이라 말 할 수 있다.

커뮤니티 아트의 대상은 공동체 구성원으로 예술을 통해 공동체의 가치 변화를 이끌어 내는 말이기도 하다 [26]. 이는 시민예술의 문화예술 지원정책인 문화를 통 한 시장 활성화, 다문화활성화, 도시재생, 창조도시, 문 화도시 등 다양한 정책마련이 실시되고 있다. 즉 커뮤 니티 아트 정책은 도시화로 쏠리는 경향에서 이른바 소 외된 이웃이 생기고, 지역문화나 전통적 공동체의 와해 현상을 예술을 통해 개선하고자 하는 문화적 정책이라 할 수 있다.

외국의 경우 정책주도형 커뮤니티 아트의 사례는 현 재 여러 가지 문제점이 야기 되고는 있으나, 한국의 경 우 다문화 가정의 증가 추세나 지역축제의 장이 난립하 고 있는 실정에서 커뮤니티 아트라는 정의 자체는 유용 한 개념이 아닐 수 없다. 예술을 통한 소통의 개념, 참 여의 개념으로 대중의 지속적인 관심을 이끌어내기 위 한 커뮤니티의 실천은, 사회현상을 위한 제도이기 이전 에 한국전통예술과 문화의 대중적 확산을 의미하기 때 문이다.

세계화를 실연하고 고유성을 지닌 한국 전통춤의 콘 텐츠를 개발하기 위해서는 글로컬라이제이션의 방안에 서 보편성을 논한 바 있다. 보편성의 원리는 친숙함에 있어서 누구나 할 수 있는 공감과 참여에 있다 해도 과 언이 아니다. 특히 우리의 전통춤은 순수예술의 영역에 서 아직은 대중화 실현이 멀게만 느껴진다. 콘텐츠 개 발의 원형과제가 너무나 제한적인 것도 바로 이 때문이 리다. 이를 위해서는 바로 커뮤니티 아트 시스템의 장 점을 도입할 필요가 있다.

거듭 강조하지만 커뮤니티 아트는 일반시민이 참여 하고, 지역문화의 진흥을 도모하는 참여하는 예술이다.
이러한 주체는 공공기관이 될 수도 있고 시민이나 예술 인이 주도할 수도 있다. 즉 생활 속의 예술정책이 될 것 이다. 예를 들어 도심에서 점심시간을 이용해 짤막한 무료관람을 즐긴다거나, 지역 축제를 관람을 전국적으 로 확대하기 위해 기념품을 주는 것도 방법이다. 공연 을 관람 한 후에는 공연 평, 문화체험기, 더 나은 공연 기획안 등을 공모하여 공공정책의 일환에서 대중의 관 심을 유도하는 것이다. 또한 다문화 가정을 위해 무료 로 한국춤을 배울 장소를 마련해서 자연스럽게 문화적 참여를 유도하고 우리문화예술을 이해하기 위한 노력 을 들 수 있다.

하지만 탁상공론에 불과한 듯 현시점에서는 시민이 나 예술가의 참여는 거의 봉사수준으로 큰 활성화의 성 과는 거두지 못하고 있다. 이점은 민간 예술가의 참여 를 제한하고 기관에 소속되어 있는 춤 단체나 소수의 단체를 이끄는 홍보용 마케팅 정도에 그친다. 따라서 장기적으로 볼 때 다양한 ‘춤꺼리’를 제공하지 못하고 일률적이고 획일적인 전통소재의 반복기획 공연 속에 서 시민의 참여조차 볼거리에 지나지 않는다는 평가를 받고 있다. 이는 춤 뿐 아니라 전통놀이 콘텐츠의 대중 적 인식과 통합적- 보편적 가치 실현에 큰 걸림돌이 되 고 있다.

시민의 참여는 소통으로 이어지고 자연스런 참여를 통해 우리 문화의 인식이 확산되는 것이다. 또한 여러 가지 문화를 교류하고 실천함으로써 대중이 좋아하는 보편적 가치를 체득함으로써 창조적 아이디어를 얻게 된다. 춤 콘텐츠의 OSMU는 문화콘텐츠의 효율적인 전 략이다. 이를 통해 춤 콘텐츠의 MS(Multi Source)가 $\mathrm{MU}($ Multi Use)화를 실현하기 때문이다.

따라서 커뮤니티 예술 정책은 무조건적인 기관이나 무대의 지원에 그칠 문제가 아니다. 하드웨어 보다는 소프트웨어의 정책적 방안이 우선시되어야만 한다. 이 를 위해서는 첫째, 대중의 유도와 관심을 끌 수 있는 우 리춤 문화원형의 소재를 단계별로 계획하고, 시험단계 에서는 전담 조직과 시민들의 반응을 살피며 대중적인 소스를 찾아내야만 한다. 둘째, 위의 스토리텔링을 중심 으로 한 춤 공연 또는 함께 참여하는 교육의 장이 같이 병행되어야만 할 것이다. 보고 즐기는 공연만으로는 '소 통'이라는 관점에서 대중화에 있어 더딘 효과를 가져 
오기 때문이다. 셋째, 더욱 참신한 예술의 원천 소스는 현재 널리 알려진 단체의 춤이나 문화재춤에 있지 않 다. 그러므로 문화재를 발견하고 찾던 초심으로 돌아가 전문기획력을 가진 기획자를 양성해야 한다. 이들의 필 드워킹에 관한 지원과 중앙무대의 통로를 확산하여 다 양한 숨은 예술가들이 선보일 수 있는 전문적인 지원책 이 마련되어야 한다.

문화재는 문화재 자체가 콘텐츠인 동시에 그 결과로 만들어진 콘텐츠가 하나의 문화재가 될 수 있다는 점을 주목해야 한다[27]. 전통문화의 계승에 관해 문화재 관 리국이나 기관은 원형의 보존과 유지에만 급급하고 있 다. 지역문화를 토착화한 참신한 현재의 전통춤을 통해 독창적인 한국적 양식으로 발전할 수 있는 토대를 함께 구축해야만 한다.

$\mathrm{MSMU}$ 의 콘텐츠 개발은 과거의 유산을 현재의 문화 자본으로 만들 수 있는 보고다. 그러한 문화자본을 위 해 필요한 것은 과거의 답습이 아니라 현재의 한국적 가치를 발견하고 과거의 문화를 융합해 나아가는 과정 에 있다. 그러기 위해서는 전통춤의 가치전환이 필요하 다. 새로운 가치창출의 인식으로 전통의 원형을 새롭게 재조명하고 창조적인 역량을 도모하는 것은 커뮤니티 를 위한 소통과 참여, 나눔의 문화에서 온다. 가장 한국 적 문화라는 가치인식은 전통의 문화적 인지가 자연스 럽게 대중의 몸에 배이고, 그것을 통해 공동의 가치관 을 가지게 될 때 바로 한국문화의 정체성으로 살아 있 는 것이다.

\section{IV. 맺음말}

전통춤 디지털콘텐츠화를 중심으로 '문화원형 디지 털 사업 현황을 살펴봄과 아울러 현시점에서 원형복원 의 현대적 가치를 재조명해 봄으로써 문화예술정책의 활용 방안에 대해 살펴보았다. 콘텐츠 가운데 전통춤은 당연히 진흥되어야 할 우선적인 과제임에도 지금까지 는 원형보존 차원이나 복원의 차원에 그치고 있으며 과 제도 매우 한정적이라 할 수 있다.

중요한 점은 전통춤 디지털콘텐츠화에 있어 전통춤 원형에 관한 기술 인력 전문성의 부족과 고증절차의 신
뢰성을 확보하는 방법이 마련되어 있지 않다는 점이다. 또한 현재 산학 협력단의 협동과제와 전문 인력 배치에 도 불구하고, 민간차원에서 콘텐츠 지식 기반을 마련할 수 있는 효율적인 정책은 아직 없다. 이에 본 연구는 전 통춤 디지털 콘텐츠 활용방안의 영역에 관해 다음과 같 이 지적한다.

첫째, 거버넌스 구축을 통해 단기적으로 기초 원형 소스의 인문학적 콘텐츠 디지털화를 선도하고, 장기적 으로는 믿고 신뢰할 수 있는 문화상품으로의 OSMU (One-Source Multi-Use)를 극대화 할 수 있다는 방안 이다.

둘째, 지역춤의 소통과 대중화의 방안으로 글로컬라 이제이션과 커뮤니티 아트 시스템 구축은 무엇보다 '문 화의 대중화’를 선도하고 전통춤의 원형과제의 MSMU 를 실현하는 정책을 의미한다. 이런 의미에서 지역축제 마케팅은 기초적인 문화예술의 상품화전략으로 충분하 다. 다만 전통춤을 대중에게 알리기 위해서는 그에 맞 는 상품화 전략이 지자체에 그칠 것이 아니라, 정부기 관이나 문화예술단체의 교류 속에서 많은 자료들을 공 유하고 실천해 나아가는 방법을 도모할 필요가 있다.

전통춤 문화원형은 바야흐로 순수예술을 뛰어넘어 콘텐츠로서의 고부가 산업의 영역이다. 또한 문화적 취 향이 경제 자본의 영향을 받기도 한다는 연구[28]가 있 다. 아직은 대중화의 인식에서 멀게 느껴지는 전통춤 공연이 다시 부활하기 위해서는 지역축제의 장이나 다 양한 커뮤니티 활성화를 통해 경제적 부담을 넘어서서 다양한 접근방안을 검토하고 소통을 위한 정책을 마련 해야 할 것이다. 민간단체에서의 인력 양성과 수급문제, 예산확보, 개인 및 민간기업의 문화진흥정책과제 협력 이라는 산업적 인식은 아직도 멀게만 느껴진다. 이러한 점은 문화원형과제가 당장의 부가가치를 창출해 내는 사업이라 보기 어렵고 기업 중심의 메세나 운동이 전통 춤에 투자할만한 가치 인식 등의 부족이라 할 수 있다.

이를 위해서는 콘텐츠 개발이라는 하드웨어적인 정 량적 확대기반을 조성하기 전에, 대중의 소통과 참여와 나눔을 통해 소프트웨어적인 정책 방안을 마련해야 할 필요가 대두된다. 예를 들어 정책마련의 행정권 안에서 만들어진 국내 야외공연장만 해도 전통춤 콘텐츠를 고 려하지 않은 채 설계된 구조 등은 다양한 문화원형의 
창의적 소재를 알리고 전통춤을 소통하기에는 여러 가 지 한계[29]를 지닌다.

이를 통한 전통춤의 자연스런 가치인식의 변화는 전 통춤 원형의 상호협력적인 구축 시스템을 통해, 창조적 보고로서 또 공공산업으로서 경제적 가치에 부흥하는 사업임이 확실시 될 것이다.

이러한 점에서 대중화 전략의 가치 인식변화는 중요 한 과제가 된다. 공공연한 문화예술단체와 국가 문예정 책은 참여하는 대중예술의 직간접적인 후원자로서의 역할을 당연히 할 수 있어야 하며, 이러한 정책을 위해 서라도 문화예술정책의 새로운 패러다임을 위한 부흥 책을 현 정부의 문화예술정책이라는 시점에서 신중히 고려해 보아야 할 것이다.

\section{참 고 문 헌}

[1] Easton, David, Systems Analysis of Political Life, New York: Wiley, p.358, 1953.

[2] 노시평, 박희서, 박영미, 정책학, 서울:학현사, pp.3-4, 1999.

[3] 샤르칸스키(Sharkanskym) Ira, Public Adminstration: Policy-Making In Government Agencies, 3rd ed., Chicago: Rand McNally Co, 1975.

[4][5] 안선국, 한국의 전통공연예술 정책에 관한 연 구, 한양대학교 행정대학원 석사학위논문, p.12-13, 2004.

[6] 임희섭, "한국사회의 발전과 문화”, 전환기시대의 문화와 문화변동, pp.37-38, 1987.

[7] 서종대, 한국전통문화의 형성과 특징에 관한 연구 - 60년대 이후 무형문화재 마당종목을 중심으로, 서울대학교 대학원 석사학위논문 p.18, 1994.

[8] 김정수, "국제화·세계화 시대의 한국행정의 진로", 한국행정연구원, p.45, 1995.

[9] 이용학, 무형문화재 전승- 보존 활성화 방안에 관 한 연구, 연세대학교 행정대학원 석사학위논문, p.20, 1999.

[10] 김교빈, “문화원형의 개념과 활용”, 인문콘텐츠
제6호, 인문콘텐츠학회, p.11, 2005.

[11] 안지영, 문화원형 디지털콘텐츠화 사업을 중심 으로 본 무용콘텐츠 활성화 방안 연구, 한양대학 교 석사학위논문, p.12, 2008.

[12] 배수율, 디지털 무용콘텐츠에 대한 가치 인식 조 사와 발전 방향, 경희대학교 대학원 박사학위논 문, p.28, 2006.

[13] 정민, 조성문, 이인호, 최형욱, “한·중 전통문화 관련 디지털 인문콘텐츠 실태 비교 및 수준 향상 방안 연구”, 한국학 논집, 제36집, p.153, 2002.

[14] 김기헌, 문화원형 디지털 콘텐츠화 사업의 발전 방향 연구, 중앙대학교 예술대학원, 석사학위 논 문, p.12, 2010.

[15] 이헌숙, 문화예술 정책이 경제적 가치에 미치는 영향에 관한 연구, 중앙대학교 대학원 석사 학위 논문, p.17, 2012.

[16] 최재승, 문화를 읽는다, 미래를 본다: 21 세기 한 국문화정책의 방향 모색, 서울:나무와 숲, pp.7781, 2011.

[17] 임학순, “한국 문화정책 연구 경향 분석(19982007)”, 문화정책논총, 제21집, pp.99-104, 2009.

[18] 김정연, 김재웅, "한국 애니메이션에 있어 문화 정책의 영향과 그 변용”, 한국콘텐츠학회논문지, Vol.7, No.12, pp.55-65, 2007.

[19] 1966년 미국 체이스 맨해튼 은행 회장이던 데이 비드 록펠러가 기업의 사회공헌 예산 일부를 문 화예술 활동에 할당하한 것이 메세나 운동의 계 기가 되었다다. 각국으로 확산되어 현재 25개국에 32 개 메세나 협의회가 있다. 한국에는 1994년 4월 한국메세나협의회가 발족돼 현재 185 개 기업이 참여 중이다. 매경닷컴.

[20] 김기헌, 앞의 논문, p.98, 2002.

[21] 롤런드 로버트슨, 세계지역화: 시간, 공간과 동 질성, 이질성, 윤민재 편저, 근대성 탈근대성 그리 고 세계화, p.73, 2000.

[22] 김재영, "원형이론의 이해: 칼 융과 그 이후 의 논리를 중심으로”, 인문학 콘텐츠 워크샵 자료, pp.2-16, 2005. 
[23] 김진영, “문화콘텐츠 신전략과 개발모형 연구”, 동국대학교 대학원, 석사학위 논문, p.14, 2011.

[24] 경기문화재단, 경기 북부형 커뮤니티아트 모델 네트워크화 최종보고서, p.75, 2009.

[25] 한국도시지리학회, "지방도시 경쟁력 창출을 위 한 커뮤니티 활성화 사업방안 연구”, 2008, 오세 형, 커뮤니티 아트의 유형과 사례연구, 성공회대 학교 석사학위 논문, p.5, 2011. 재인용.

[26] 노수정, 커뮤니티 아트의 현황과 활성화 방안 연 구, 단국대학교 경영대학원 석사학위 논문, p.7, 2009.

[27] 김진영, 위의 논문, p.22, 2011.

[28] 이성호, 김말애, "체육공원내의 야외공연장 건립 에 관한 법제”, 한국콘텐츠학회논문지, Vol.12, No.1, p.212, 2012.

[29] 전범수, "문화예술 취향 레퍼토리 구조 연구", 한 국콘텐츠학회논문지, Vol.12, No.6, pp.201-210, 2012.

\section{저 자 소 개}

\section{김 지 원(Ji-Won Kim)}

정회원

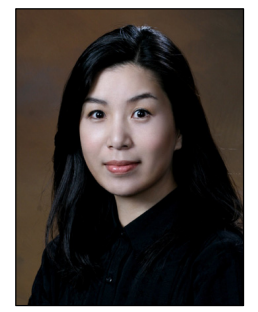

- 현재 : 단국대 대학원 행정학과 박사과정

- 현재 : 선문대·한국종합예술학 교 외래교수

- 현재 : 공연문화학회 편집위원 <관심분야> : 문화예술정책

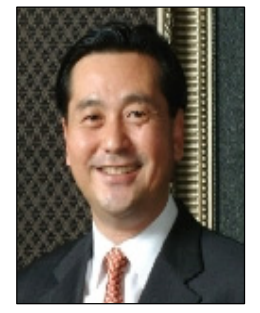

- 현재 : 단국대학교 사회과학대학 행정학과 교수

- 현재 : 단국대학교 행정법무대학 원 원장 <관심분야> : 정책이론 문화정책 